\title{
Mangrove Flora and Fauna of Klang Islands Mangrove Forest Reserves, Selangor, Malaysia
}

\author{
Norhayati, A. ${ }^{1,2}$, Shukor, M.N. ${ }^{1}$, Juliana, S. ${ }^{2}$ and Wan Juliana, W.A. ${ }^{1}$ \\ ${ }^{1}$ School of Environmental \& Natural Resource Sciences, Faculty of Science \& Technology, ${ }^{2}$ Institut for \\ Environment \& Development (LESTARI), Universiti Kebangsaan Malaysia, Selangor Darul Ehsan, Malaysia. \\ *noryati@ukm.my (corresponding author) \\ Received on $26^{\text {th }}$ Febuary 2008, accepted in revised form $30^{\text {th }}$ September 2009.
}

\begin{abstract}
The mangrove areas of the Klang Islands Forest Reserves, Selangor, have been declining in size and quality due to degazettement or removal from legal protection of the forest reserves and subsequent land reclamation and other development activities. Thus, surveys on mangrove flora and fauna were conducted to assess current status and identify impact of development. A list of mangrove flora and fauna is produced. Terrestrial vertebrates (mammals, birds and herpetofauna) surveyed revealed a total of 68 species ( 8 species of mammals, 57 species of birds and 3 species of reptiles). Species composition and total standing above-ground biomass of mangrove trees in ten $10 \times 10 \mathrm{~m}$ plots, totalling 0.4 ha area, were estimated at Pulau Indah and Pulau Che Mat Zin. Both islands are within the Klang Islands Mangrove Forest Reserves (MFR), which have been declining in forest cover. The total number of individual trees recorded in all 10 plots was 222 from 10 species of three families i.e. Rhizophoraceae, Avicenniaceae and Meliaceae. Rhizophora apiculata was the most dominant tree species with an Important Value Index (IVI) of 28.2, contributed mainly from the density (77 trees). The total basal area of the trees was of $23.96 \mathrm{~m}^{2} /$ ha with $R$. apiculata making up most of the total value of $6.96 \mathrm{~m}^{2} / \mathrm{ha}$. The estimated total aboveground biomass of mangrove trees in this study was $2300.1 \mathrm{~kg} / 0.1$ ha with the highest contribution from $R$. apiculata and Bruguiera gymnorrhiza. The estimated biomass was very low compared to other pristine mangrove forest at Matang or Langkawi. The causal factors identified included clear-felling activity, coastal erosion caused by wave actions from ships, oil pollution, reclamation, and other development activities.
\end{abstract}

\begin{abstract}
ABSTRAK Kawasan bakau di Hutan Simpan Pulau-pulau Klang, Selangor, semakin berkurangan daripada segi luas dan kualiti kerana sebahagian kawasan telah digazet atau dikeluarkan daripada kawasan hutan simpan untuk ditebusguna tanah atau untuk pembangunan lain. Oleh itu, tinjauan terhadap fauna bakau dijalankan untuk mengenalpasti status terkini dan impak pembangunan. Satu senarai flora dan fauna bakau dihasilkan. Vertebrat darat (mammalia, burung dan herpetofauna) yang ditinjau terdiri daripada sejumlah 68 spesies ( 8 spesies Mammalia, 57 spesies burung dan 3 spesies Reptilia). Komposisi spesies dan biojisim pokok bakau dalam 10 plot bersaiz 10 x 10 $\mathrm{m}$, atau kawasan seluas 0.4 ha dianggarkan di Pulau Indah dan Pulau Che Mat Zin. Kedua-dua pulau merupakan sebahagian daripada Hutan Simpan Pulau Klang. Jumlah pokok bakau yang direkod dalam semua plot ialah 222 daripada 10 spesies dalam tiga famili i.e. Rhizophoraceae, Avicenniaceae and Meliaceae. Rhizophora apiculata ialah pokok yang paling dominan dengan Indek Nilai Kepentingan sebanyak 28.2, yang disumbang oleh kepadatan pokok spesies tersebut iaitu sebanyak 77. Jumlah keluasan pokok ialah $23.96 \mathrm{~m}^{2} / \mathrm{ha}$, yang mana R. apiculata menyumbang nilai tertinggi iaitu $6.96 \mathrm{~m}^{2} / \mathrm{ha}$. Anggaran jumlah biojisim pokok bakau di kawasan kajian ialah $2300.1 \mathrm{~kg} / 0.1 \mathrm{ha}$ dengan sumbangan tertinggi daripada R. apiculata dan Bruguiera gymnorhiza. Nilai anggaran biojisim sangat kecil jika dibandingkan dengan nilai hutan bakau primer di Matang atau di Langkawi. Faktor penyebab yang dikenalpasti ialah hutan bakau di sini mengalami tekanan fizikal daripada pembangunan di sekeliling seperti pembalakan, aktiviti tebusguna tanah, hakisan pantai yang disebabkan oleh tindakan ombak dari laluan kapal, pencemaran minyak dan aktiviti pembangunan lain.
\end{abstract}

(Keywords: vertebrates, small mammals, birds, bats, herpetofauna, biomass)

\section{INTRODUCTION}

Two major rivers in Klang, Sg. Klang and Sg. Langat, drain into nearby coastal area, with a coastline of $53.75 \mathrm{~km}$ (Klang Municipal Council 2000). There are three main islands surrounding Port
Klang: Pulau Klang, Pulau Ketam and Pulau Carey. The major vegetation here is mangrove and the largest forest reserve is known as the Klang Islands Mangrove Forest Reserve (KIMFR). The mangrove forests are subjected to rapid development, which might jeopardize environmental and social 
conservation. Management of natural resource becomes a real challenge when control and reduction of pollution is more pressing an issue. Additionally, Port Klang (North Port and South Port) and West Port (Pulau Indah) are busy ports, handling millions of metric tons of cargo, and increasing by the year. Since mangroves are declining from year to year, wildlife components are targets that are potentially affected by development. The mangrove areas at the West Port, for example, have been exploited for land clearing, reclamation, selective logging, aquaculture, agriculture and other development activities [1, 2, 3]. In 1998, the KIMFR was estimated to be $10,871.4$ ha, which was $88 \%$ of the 12,301 ha in 1984 [4]. This loss may have had adverse ecological and economical impacts arising from impairment of ecological functions and services provided by the mangroves. Impacts may include degradation and/or loss of habitat and nursery grounds, reduction of biodiversity, loss of natural protection and subsequent coastal erosion and siltation, loss of carbon storage, and reduction of detritus. Ultimately, the adverse effects may also affect livelihood of local fishermen. Thus, it is crucial to obtain information on the flora and fauna of this area, for development of a management plan for sustainable development of the area. In this study, emphasis was given to trees $>10$ $\mathrm{cm} \mathrm{dbh}$ and four animal groups namely birds, reptiles, mammals and amphibians. These biological components are considered important in assessing the natural state of mangrove ecosystem.

Many methods have been employed to study biomass including litterfall method [5], harvesting method [6] and light attenuation method [7]. With the development of regression of biomass from the allometric techniques $[8,9,10]$, the standing biomass can be easily estimated from simple-to-measure parameters such as dbh and tree height. Using this method, estimation of biomass is no longer a destructive and time-consuming measure. The total stand biomass is obtained by summing up the weight of single trees over the area specified. Thus, the objectives of this study were to determine species composition and to estimate total standing aboveground biomass of mangrove trees in ten $10 \times 10 \mathrm{~m}$ plots, totalling 0.4 ha area, in the selected sites at Pulau Indah and Pulau Che Mat Zin. Both islands are within the KIMFR, which have been declining in cover due to degazettement or removal from legal protection of the forest reserves and subsequent land reclamation and other development activities.

\section{STUDY SITES AND METHODS}

\section{Flora and biomass}

Plot establishment and field surveys on tree species composition and other measurements were conducted in October 2003. The first site was located at Pulau Che Mat Zin in compartment 35 of Che Mat Zin Forest Reserve, while the second site was at Pulau Indah, partly in compartment 10 and 3 of Pulau Indah Forest Reserve (Figure 1). Pulau Che Mat Zin $\left(2^{0} 55^{\prime}-59^{\prime} \mathrm{N}, \quad 101^{0} 16^{\prime}-19^{\prime} \mathrm{E}\right)$ is located between Pulau Selat Kering, Pulau Kelang and Pulau Indah (previously Pulau Lumut). This island comprised mainly mangrove forest with some intertidal mudflats to the west and east. Pulau Indah is located in the innermost of the Klang Islands $\left(2^{0} 53^{\prime}-3^{0} 00^{\prime} \mathrm{N}\right.$, $101^{0} 17^{\prime}-22$ 'E). The sampling plots consisted of 5 plots of $10 \times 10 \mathrm{~m}$ arranged along a line-transect at each site. The total area sampled was $500 \mathrm{~m}^{2}$ or 0.05 ha in each study site or 0.01 ha for all ten plots. All the plots were numbered from 1-5 (herewith known as Site A) followed by 6-10 (site B) for the second transect. The exact locations of the plots are shown in Table 1. Measurements of DBH involved marking a tree $\geq 5 \mathrm{~cm} \mathrm{dbh}$, at its point of measurement (p.o.m.) $1.3 \mathrm{~m}$ above ground level or $20 \mathrm{~cm}$ above its buttress. Measurements were made using a fibreglass diameter tape. Standard procedures suggested by Lugo \& Snedaker [11] when measuring tree diameter were followed.

\section{Analysis of measurements Basal area}

Basal area (BA) is the proportion of ground covered by tree stems. It is the cross section of the stem at a point where $\mathrm{DBH}$ is measured. The BA of a stand is the sum of the individual basal area of all trees $\geq 10$ $\mathrm{cm}$ dbh per unit area. It is computed using the formula $\mathrm{BA}=\pi \mathrm{r}^{2}$, and since $\mathrm{r}=\mathrm{DBH} / 2$, thus, $\mathrm{BA}=\pi / 4\left(\mathrm{DBH}^{2}\right)$, expressed in $\mathrm{m}^{2} / \mathrm{ha}$.

\section{Absolute density, absolute frequency and absolute dominance}

Absolute density of a stand is the number of trees greater or equal to the specified dbh per unit area. A forest with a tree species whose dominance is 40 or more is called a mono-dominant or single-dominant forest. The formulae for calculating absolute density, dominance and frequency are given below:

Absolute frequency, $\mathbf{F}_{\mathbf{A}}=$ percentage of points where the species or family occurs

Absolute density, $\mathbf{D}_{\mathbf{A}}=$ number of individuals of a species or family / ha

Absolute dominance, $\mathbf{D o}_{\mathbf{A}}=$ Total BA of a species or family / ha 
Table 1. GPS locations of the mangrove sampling plots of $10 \times 10 \mathrm{~m}$ each.

\begin{tabular}{cc}
\hline Plot Number & GPS Location \\
\hline 1 & $\mathrm{~N} 2^{0} 55.610^{\prime} \mathrm{E} 101^{0} 16.88^{\prime}$ \\
2 & $\mathrm{~N} 2^{0} 55.623^{\prime} \mathrm{E} 101^{0} 16.88^{\prime}$ \\
4 & $\mathrm{~N} 2^{0} 55.690^{\prime} \mathrm{E} 101^{0} 16.87^{\prime}$ \\
5 & $\mathrm{~N} 2^{0} 55.704^{\prime} \mathrm{E} 101^{0} 16.89^{\prime}$ \\
6 & $\mathrm{~N} 2^{0} 55.732^{\prime} \mathrm{E} 101^{0} 16.93^{\prime}$ \\
7 & $\mathrm{~N} 2^{0} 53.751^{\prime} \mathrm{E} 101^{0} 16.55^{\prime}$ \\
8 & $\mathrm{~N} 2^{0} 53.759^{\prime} \mathrm{E} 101^{0} 16.57^{\prime}$ \\
9 & $\mathrm{~N} 2^{0} 53.783^{\prime} \mathrm{E} 101^{0} 16.59^{\prime}$ \\
10 & $\mathrm{~N} 2^{0} 53.744^{\prime} \mathrm{E} 101^{0} 16.58^{\prime}$ \\
\hline
\end{tabular}

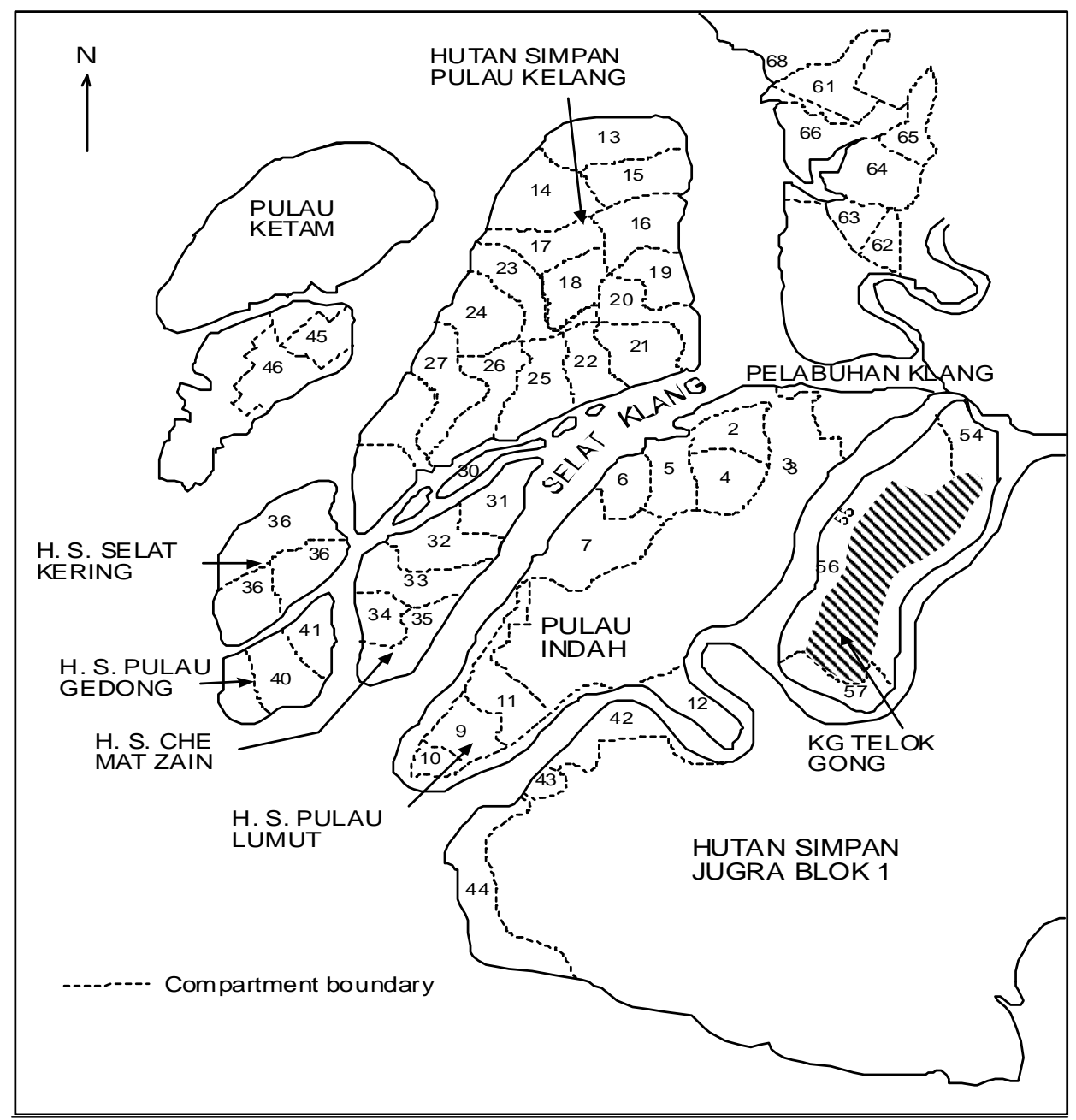

Figure 1. Location of compartments where the study plots were established. 


\section{Relative density, relative dominance and relative frequency}

These parameters are useful to describe plant community and are used to interpret the importance of the contribution of each component species to the stand in terms of density, contribution to basal area (dominance) and the probability of occurrence throughout the plots (frequency). The formulae for calculating these parameters are as follows:

Relative density, $\mathbf{D}_{\mathbf{R}}=$ total individual of a species/total number of individuals x 100

Relative dominance, $\mathbf{D o}_{\mathbf{R}}=$ total $\mathrm{BA}$ of $\mathrm{a}$ species/total BA of all species x 100

Relative frequency, $\quad \mathbf{F}_{\mathbf{R}}=$ frequency of a species/total frequency of all species x 100

Importance Value Index (IVI) and Family Importance Value (FIV)

Importance Value Index for each species of trees was calculated as the sum of its relative density, dominance and frequency [12] or IVI $=D_{R}+D_{R}+$ $\mathrm{F}_{\mathrm{R}}$. An IVI index of more than 10 is considered as dominant for a tropical forest species. For a certain family, the Family Importance Value (FIV) is the sum of its relative density, diversity and dominance
[13]. Both IVI and FIV describe the social structure of species and family in a community and can be used to form an association of dominant species and family. They are important measures of the contribution of certain species or family to the whole stand.

\section{Biomass}

The allometric equation adopted from Clough and Scott [10] was used to estimate standing aboveground biomass. The allometric equations describe relationships for estimating leaf, branch, stem, and total above-ground biomass of species Rhizophora apiculata, Xylocarpus granatum, Bruguiera parviflora, B. gymnorhiza and Ceriops tagal (Table 2). The formula for estimating biomass is as follows:

$$
\log \text { Biomass }=\mathrm{A}+\mathrm{B} \log _{10} \mathrm{dbh}
$$

$\mathrm{A}$ and $\mathrm{B}$ are constants. Equation (1) can be simplified where $B$ values are the same as in Equation (1) and $A_{p}$ are the antilogs of $\mathrm{A}$ in Equation (1). Thus,

$$
\text { Biomass }=A_{p} \cdot d b h^{B}
$$

\begin{tabular}{|c|c|c|c|c|c|}
\hline Species & Variable & $\mathbf{A}$ & $B$ & $\mathbf{r}^{2}$ & $\mathbf{E}$ \\
\hline $\begin{array}{l}\text { B. gymnorhiza } \\
\mathrm{n}=17 \\
2-24 \mathrm{~cm} \mathrm{dbh}\end{array}$ & Total & -0.7309 & 2.3055 & 0.989 & 1.19 \\
\hline $\begin{array}{l}\text { B. parviflora } \\
\mathrm{n}=16 \\
2-21 \mathrm{~cm} \mathrm{dbh}\end{array}$ & Total & -0.7749 & 2.417 & 0.993 & 1.17 \\
\hline $\begin{array}{l}\text { C. tagal } \\
\mathrm{n}=26 \\
2-18 \mathrm{~cm} \mathrm{dbh}\end{array}$ & Total & -0.7247 & 2.3379 & 0.989 & 1.16 \\
\hline $\begin{array}{l}\text { R. apiculata } \\
\mathrm{n}=23 \\
3-23 \mathrm{~cm} \mathrm{dbh}\end{array}$ & Total & -0.9789 & 2.6848 & 0.995 & 1.11 \\
\hline $\begin{array}{l}X \text { granatum } \\
\mathrm{n}=15 \\
3-17 \mathrm{~cm} \mathrm{dbh}\end{array}$ & Total & -1.0844 & 2.5883 & 0.994 & 1.13 \\
\hline
\end{tabular}

Table 2. Allometric regressions of above-ground biomass on dbh for six mangrove tree species.

Source: Clough and Scott (1989)

$\mathrm{A}$ and $\mathrm{B}$ are constants in the equation $\log$ Biomass $=\mathrm{A}+\mathrm{B} \log \mathrm{DBH}, \mathrm{r}^{2}$ is the correlation coefficient, $\mathrm{E}$ is the standard error of the biomass estimate, and $\mathrm{n}$ is the number of trees sampled within the indicated $\mathrm{DBH}$ range. Biomass is in $\mathrm{kg}$ and $\mathrm{DBH}$ in $\mathrm{cm}$.

* includes buttress roots. 


\section{Fauna}

Field sampling was conducted for 3 full days in September $\left(12-14^{\text {th }}\right)$, October $\left(15-17^{\text {th }}\right)$ and December $\left(18-20^{\text {th }}\right)$ 2003. Daily samplings (trapping and observation) were conducted during low tide, which was only 4-5 hours a day. Surveys and trappings were concentrated at the following areas:

i) An open reclaimed coastal area of barren sandy ground without any structures,

ii) Shoreline along the southwest coast encircling the proposed area and shoreline along the Pulau Che Mat Zain fronting the proposed area.

iii) Low-lying wetlands with mangroves and nipah palms that are inundated by seawater during high tides at the southwest coast and on Pulau Che Mat Zain primarily forest compartments fronting the proposed site.

iv) Orchards and plantations partly within and at adjacent proposed areas.

Generally, much of the areas surrounding the existing port were reclaimed, originally were either swamp or primarily mangrove forests. Several parts of the surrounding areas have already been converted into plantations (e.g. coconut) and majority of the reclaimed areas are either developed into port amenities, such as storage facilities, mills and housing. Inland of the area are villagers (e.g. fisherman) who have already established themselves even before the port was developed. The existing reclaimed area that was designated for the expansion project is an open area covered by grasses, shrubs and secondary vegetation. Facing the existing port at the northwest is the Pulau Che Mat Zain, reported by local authorities as not inhabited by humans, although signs of human activities were observed.

\section{Terrestrial large and small mammals}

Two common methods were used, trapping and field observation. Trapping was made along several trails representing the most prominent habitats. Along each of this trail, 50 traps were laid at $10-15$ m intervals. Traps were baited alternately with, either banana, roasted coconut meat, ripe jack fruit, and oil palm. Traps were serviced twice a day, morning and evening and left open for at least one night. Each trapped mammal was examined for species identification, and released at the point of capture. Field night and day surveys were conducted along these trails using $40 \times 10$ binoculars.

\section{Birds and Bats}

Along the trails set for small mammals, at least five mist-nets were set up, opened during the day for birds and at night for bats. For birds, nets were inspected every two hours twice in the morning and twice in the evening. Birds netted were released after identification. Apart from the mist nets, harp traps were also used to catch bats. Additionally, observations were made along the shore line and mangrove habitat to identify bird species.

\section{Herpetofauna}

Along the trails, during mammal surveys, frogs and snakes were opportunistically sampled or recorded.

\section{RESULTS AND DISCUSSION}

\section{Mangrove plant species composition and biomass estimation}

The total number of individual trees recorded in all 10 plots was 222 from 10 species of three families i.e. Rhizophoraceae, Avicenniaceae and Meliaceae. The list of mangrove tree species in the plots is shown in Table 3. Rhizophora apiculata was the most dominant tree species with an Important Value Index (IVI) of 28.2, followed by Ceriops tagal (17.7) and Bruguiera cylindrica (11.4; Table 4). Density of $R$. apiculata was the highest of all the species with 77 trees. The mean dbh for Avicennia marina was the highest at $32.5 \pm 9.9 \mathrm{~cm}$, followed by Xylocarpus granatum, at $13.1 \pm 3.1 \mathrm{~cm}$ and $B$. gymnorhiza, at $11.7 \pm 2.1 \mathrm{~cm}$. The total basal area of the trees was of $23.96 \mathrm{~m}^{2} /$ ha with $R$. apiculata making up most of the total value at $6.96 \mathrm{~m}^{2} / \mathrm{ha}$, followed by A. marina $\left(4.60 \mathrm{~m}^{2} / \mathrm{ha}\right)$ and $R$. mucronata at $\left(3.67 \mathrm{~m}^{2} / \mathrm{ha}\right)$. General surveys conducted around the area revealed other species such as A. alba (tree), Sonneratia alba (tree), Hibiscus tiliaceus (shrub), Scyphiphora hydrophyllacea (shrub/tree), Nypa frutican (palm), Excoecaria agallocha (shrub/tree), and Acrostichum aureum (fern). A study by Adam et al. [14] at Klang Port area reported only two species; $R$. mucronata and $B$. gymnorhiza. The study was based on three plots, each of size $20 \times 50 \mathrm{~m}$, located at the upper, middle and lower part of Klang River. 
Table 3. List of mangrove tree species sampled in the plots.

\begin{tabular}{llll}
\hline No. & Species & Family name & Common name \\
\hline 1 & Avicennia marina (Forsk.) Vierh. & Avicenniaceae & Api-api jambu \\
2 & Bruguiera cylindrica Bl. & Rhizophoraceae & Berus \\
3 & B. gymnorhiza (L.) Lamk. & Rhizophoraceae & Tumu merah \\
4 & B. parviflora (Roxb.) W. \& A. ex Griff. & Rhizophoraceae & Berus lenggadai \\
5 & Ceriops tagal (Perr.) C.B. Robinson & Rhizophoraceae & Tengar \\
6 & Excoecaria agallocha (L.) Lamk. & Euphorbiaceae & Buta-buta \\
7 & Rhizophora apiculata Bl. & Rhizophoraceae & Bakau minyak \\
8 & R. mucronata (L.) Lamk. & Rhizophoraceae & Bakau kurap \\
9 & Xylocarpus granatum Koenig & Meliaceae & Nyireh bunga \\
10 & X. moluccensis (L.) Lamk. Roem & Meliaceae & Nyireh batu \\
\hline
\end{tabular}

\section{Estimation of biomass}

The highest mean value of estimated biomass was contributed by $B$. gymnorhiza $(40.3 \pm 11.9 \mathrm{~kg} / 0.01$ ha), followed by $X$. granatum $(19.8 \pm 7.3 \mathrm{~kg} / 0.01 \mathrm{ha})$. Although the mean biomass for $R$. apiculata was very low $(11.9 \pm 2.2 \mathrm{~kg} / 0.01 \mathrm{ha})$, the number of standing tree of was the highest (77 trees), and thus, contributed to the high biomass (Table 5). Based on sampling plots, the range of estimated biomass was from $5.5 \pm 0.4 \mathrm{~kg} / 0.01$ ha (Plot 1 ) to $58.3 \pm 18.1$ $\mathrm{kg} / 0.01$ ha (Plot 3). The average among all the plots was $14.11 \pm 1.9 \mathrm{~kg} / 0.01 \mathrm{ha}$. The total calculated biomass was $2300.7 \mathrm{~kg} / 0.1$ ha, and when extrapolated to the unit of tonne/ha, the estimated biomass was 23.0 tonne/ha. The estimated value was extremely low when compared to $316 \mathrm{t} / \mathrm{ha}$ at Matang Forest Reserve, Perak [15]. Another estimate calculated for a pristine mangrove forest at Matang was 409 t/ha [9]. A study conducted by Fromard et al. [16], obtained above-ground biomass of mangrove forest by clear-cutting in pioneer plots, and by sampling trees in the mature mangrove forest to obtain allometric relationships. They estimated total biomass from $32 \mathrm{t} / \mathrm{ha}$ in pioneering stages to $350 \mathrm{t} / \mathrm{ha}$ in the mature stands. In a healthy coastal mangrove area, the intertidal mud and sand flats are extremely important wetland habitats that support the very rich benthic fauna, especially if the mangrove is in a phase of active accretion. The main frontline of coastal mangrove vegetation is a zone characterised by a combination of Sonneratia and Avicennia spp., followed by Rhizophora zone, and the more inland Bruguiera zone. In the study site, most trees were small, probably due to the over-harvesting of big trees, and also the big frontline trees such as Sonneratia spp. and Avicennia spp. were not abundant along the badly eroded coastline. The biomass of mangrove forest estimated in this study was considered very low, signifying a mangrove forest undergoing recovery from a clear-felling activity. Thus, proper mitigation measures to reduce stress and damage to the existing mangrove forest at the opposite coastline would have to be dealt with seriously. Such measures should probably include silt/fine sediment-trapping or bunds to prevent washaway, or protection of some portion of the forest from further development or encroachment.

There has been evidence that the forests at site A of Pulau Mat Zain had been logged a few times before, and it was observed that the vegetation has been much impoverished of the larger timber species, leaving smaller trees of little or no economic importance. This is because since the coastal zone is a transition zone between land and sea, it is an area where multiple environmental impacts are superimposed on a gradient of rapid biotic, abiotic, and ecological changes. It is also a repository for river-borne materials including pollutants, fertilizers, heavy metals, which may impact biological components of a mangrove ecosystem. For example, studies have shown that deforestation of mangrove forest adjacent to the open sea has sometimes exacerbated coastal erosions from sea waves [17, 18]. All of these factors are likely to exacerbate the impact of further development in the area, especially reclamation activities. In general, the impact of reclamation activities may change the species composition of mangrove vegetation or may destroy the forest, especially facing the open sea. 
Table 4. Mangrove forest structure in the area sampled at the West Port, Klang.

\begin{tabular}{|c|c|c|c|c|c|c|c|}
\hline Species & $\begin{array}{c}\text { No.indiv. } \\
\text { alive }^{\mathrm{a}}\end{array}$ & $\begin{array}{l}\text { Avg. dbh } \\
\text { (cm) }\end{array}$ & $\begin{array}{c}\text { Basal } \\
\text { Area }^{\mathbf{b}} \\
\left(\mathbf{m}^{2}\right)\end{array}$ & $\begin{array}{l}\text { Rel. } \\
\text { Den. }\end{array}$ & $\begin{array}{l}\text { Rel. } \\
\text { freq. }\end{array}$ & $\begin{array}{c}\text { Rel. } \\
\text { dom. }^{\text {e }}\end{array}$ & IVI $^{\mathbf{f}}$ \\
\hline Rhizophora apiculata & 77 & $8.4 \pm 0.7$ & 6.96 & 34.68 & 20.83 & 29.06 & 28.19 \\
\hline Ceriops tagal & 58 & $6.1 \pm 0.2$ & 1.95 & 26.13 & 18.75 & 8.15 & 17.68 \\
\hline Bruguiera cylindrica & 26 & $6.8 \pm 0.8$ & 1.86 & 11.71 & 14.58 & 7.76 & 11.35 \\
\hline Rhizophora mисronata & 25 & $10.3 \pm 1.5$ & 3.67 & 11.26 & 14.58 & 15.34 & 13.73 \\
\hline Bruguiera gymnorhiza & 18 & $11.7 \pm 2.1$ & 3.04 & 8.11 & 12.50 & 12.71 & 11.11 \\
\hline Xylocarpus granatum & 8 & $13.1 \pm 3.1$ & 1.60 & 3.60 & 10.42 & 6.66 & 6.89 \\
\hline Avicennia marina & 4 & $32.5 \pm 9.9$ & 4.60 & 1.80 & 2.08 & 19.21 & 7.70 \\
\hline Xylocarpus moluccensis & 4 & $8.5 \pm 0.1$ & 0.22 & 1.80 & 2.08 & 0.90 & 1.60 \\
\hline Bruguiera parviflora & 2 & $5.1 \pm 0.0$ & 0.05 & 0.90 & 4.17 & 0.19 & 1.75 \\
\hline Total & 222 & & 23.96 & 100 & 100 & 100 & 100 \\
\hline
\end{tabular}

${ }^{\text {a }}$ Number of individuals $(\geq 5 \mathrm{~cm}$ dbh) in all ten plots

${ }^{\mathrm{b}}$ Basal area $\left(\mathrm{m}^{2}\right)=\Sigma\left(\mathrm{dbh}^{2} . \pi\right) /(4.10000)$

${ }^{\mathrm{c}}$ Relative density $=$ (total individuals of a species / total number of individuals) $\mathrm{x} 100$

${ }^{\mathrm{d}}$ Relative frequency $=$ (frequency of a species / sum frequency of all species) $\mathrm{x} 100$

${ }^{\mathrm{e}}$ Relative dominance $=($ total basal area of a species / basal area of all species $) \times 100$

${ }^{\mathrm{f}}$ Important Value Index $=($ Rel. density + Rel. frequency + Rel. dominance $) / 3$.

Table 5. Estimated biomass of selected mangrove tree species at the sampling plots.

\begin{tabular}{lccccc}
\hline Biomass & $\mathrm{Bg}$ & $\mathrm{Bp}$ & $\mathrm{Ct}$ & $\mathrm{Ra}$ & $\mathrm{Xg}$ \\
\hline & & & & & \\
Mean & 40.28 & 5.45 & 8.47 & 11.88 & 19.83 \\
Standard Error & 11.85 & 0.15 & 0.67 & 2.22 & 7.25 \\
Median & 8.29 & 5.45 & 6.72 & 4.60 & 13.48 \\
Mode & 8.29 & $\mathrm{~N} / \mathrm{A}$ & 5.92 & 4.21 & 3.89 \\
Standard Deviation & 50.28 & 0.21 & 5.13 & 19.45 & 20.50 \\
Sample Variance & 2527.91 & 0.05 & 26.32 & 378.17 & 420.33 \\
Kurtosis & -0.36 & $\mathrm{NA}$ & 24.51 & 10.45 & 1.62 \\
Skewness & 1.11 & $\mathrm{NA}$ & 4.42 & 3.05 & 1.42 \\
Range & 143.45 & 0.30 & 34.10 & 110.54 & 58.23 \\
Minimum & 5.93 & 5.30 & 5.62 & 3.15 & 3.41 \\
Maximum & 149.38 & 5.60 & 39.72 & 113.69 & 61.65 \\
Sum & $\mathbf{7 2 4 . 9 8}$ & $\mathbf{1 0 . 9 0}$ & $\mathbf{4 9 1 . 0 9}$ & $\mathbf{9 1 5 . 0 7}$ & $\mathbf{1 5 8 . 6 3}$ \\
\% from total Sum & 31.5 & 0.01 & 21.3 & 39.8 & 6.9 \\
Count & 18 & 2 & 58 & 77 & 8 \\
Confidence Level(95.0\%) & 25.00 & 1.91 & 1.35 & 4.41 & 17.14 \\
\hline
\end{tabular}

$(\mathrm{Bg}=$ Bruguiera gymnorhiza $; \mathrm{Bp}=B$. parviflora $; \mathrm{Ct}=$ Ceriops tagal $; \mathrm{Ra}=$ Rhizophora apiculata $; \mathrm{Xg}=X y$ locarpus granatum) 
Jiao et al. [19] suggested that reclamation activity may not only impact around the reclamation site, but also in the coast areas opposite the reclamation site.

The existing impacts of the reclamation and the existing port (and activities) on mangrove ecosystem is already detected such as the major impact is the erosion especially along the shoreline on Pulau Mat Zain, which is facing the port. Additionally, waves created from ships along the waterways into the port also cause physical stress on the shoreline and the mangrove forest. Further erosion would lead to destruction of the mangrove ecosystem. Other identified disturbances and threats included illegal clearfelling, overexploitation, oil and solid waste pollution.

At Pulau Indah, the mudflat area, which occurs at the south-western tip, was not significant in size and extent. Most parts of the island have been developed as port area, coconut plantation, tourism (fishing spots), and housing. The remaining mangrove forest at the south-eastern tip of the island is undergoing serious erosion problem and is shrinking in size. Under such conditions and without proper management or mitigation measures, succession would not have been very successful. Additionally, the remaining mangrove forest may not sustain as rich fauna and flora as compared to other Klang islands, especially since signs of illegal logging were detected. Much of the remaining interior forest was cleared of big trees and pathways to transport logs stretched out far across the mangrove forest.

\section{Fauna}

The list of all mammal species gathered through trapping, netting and interviews are shown in Table 6. A total of 7 species of small and large terrestrial non-volant mammals were identified in which four of them were from trapping, two from direct observation and one from footprints. They represented one species each of pig, rat, squirrel, civet, and otter, and 2 species of monkeys. For volant small mammals (bat), only one species was recorded, which is a fruit bat (Pteropodidae).

\section{Mammals}

Callosciurus notatus and Rattus tiomanicus were caught in the live traps. C. notatus is a common and well distributed squirrel species in plantation and also in forest $[20,21]$, while $R$. tiomanicus is a common species inhabiting mostly islands [21]. Paradoxurus hermaphroditus is a common civet species caught in a collapsible trap. This species is also known to inhabit primarily secondary forest, plantation and gardens, but rarely in tall forests [20]. The two species of monkeys, Dusky Leaf Monkey (Trachypithecus obscurus) and Long-tailed Macaque (Macaca fascicularis) were observed roaming and feeding within the study area. M. fascicularis is common in coastal forests, including mangroves and rivers [20]. T. obscurus is also relatively common compared to other species of leaf monkeys, because this species is resilient to disturbance [20].

Wild pigs and otters also inhabit Pulau Mat Zain. Wild pig is a common island species, while otters also inhabit primarily mangrove habitat [20]. Pigs were observed scavenging and feeding on Pulau Che Mat Zain at study site facing West Port (Figure 1). At the same site, signs of otter were also found. Macroglossus minimus is a common coastal bat species, which is also found dipterocarp forest and lowland montane forest up to $1000 \mathrm{~m}$ [21]. No insectivorous species was caught at the study sites, although three harp-traps were set and left continuously for four nights.

Among these seven species, only leaf monkey, macaque, small-clawed otter, and civet are considered important species for conservation since otter and leaf monkey is listed as 'Totally Protected' whilst macaque and civet is listed as 'Protected' species under Appendix II, Wildlife Act 76 (1972). Although listed as 'Totally Protected' and 'Protected', all of these species are very common, inhabiting secondary, primary and disturbed lowland forest [20]. Under Wildlife Act 76 (1972), 'Totally Protected' species means the animals of this species cannot be harmed, caught or killed. However not necessarily all the 'Totally protected' species are endangered.

Comparatively, low number of bat and small mammal species captured from this survey was expected in coastal and mangrove habitat. Compared to other habitats, mammal diversity is expected to be low in coastal and mangrove habitat [21]. Saberi Othman et al. [22] reported only 2 species each of primates (mammals), reptiles and amphibians in mangrove habitat of Kuala Selangor. In regenerating mangrove of Kuala Kedah, Shukor and Sham [23] reported two species of fruit bats, and one species of mongoose. Uncommonly reported is Flying Fox (Pteropus vampyrus), which uses mangroves as roosting place. The best and most comprehensive study on mangrove fauna was conducted in Johor by Christensen et al., 1999 [24]. In his report, 30 mammal species (large and small including bats) were recorded from the Johor Mangrove Forests, compared to only 8 species from this survey. Among 
the 8 species, 2 were not reported by the Christensen et al. [24]: common palm civets (Paradoxurus hermaphroditus) and leaf monkey (Trachypithecus obscurus). Low number of mammal species in mangrove forest of the proposed area is associated with the size and the nature of the forest. The mangrove forest within the study area was relatively small and low in quality of forest, and probably not suitable to support many mammal species.

Table 6. Terrestrial mammal fauna recorded at the proposed area. Compilation based on individuals trapped, observation $(\mathrm{Ob})$ and foot print $(\mathrm{Fp})$.

\begin{tabular}{|c|c|c|c|c|c|c|}
\hline \multirow{2}{*}{ No. } & \multirow{2}{*}{ Family } & \multirow{2}{*}{ Species } & \multicolumn{4}{|c|}{ Habitat } \\
\hline & & & $\mathrm{P} 1$ & $\mathrm{P} 2$ & P3 & P4 \\
\hline & Viverridae & & & & & \\
\hline \multirow[t]{2}{*}{1} & Common palm civet & Paradoxurus hermaphroditus ${ }^{\mathrm{P}, \mathrm{Lr} / \mathrm{Nt}}$ & 0 & 1 & 0 & 0 \\
\hline & Muridae & & & & & \\
\hline \multirow[t]{2}{*}{2} & Malayan field rat & Rattus tiomanicus & 3 & 0 & 0 & 0 \\
\hline & Sciuridae & & & & & \\
\hline \multirow[t]{2}{*}{3} & Plantain squirrel & Callosciurus notatus & 0 & 0 & $\mathrm{Ob}$ & 2 \\
\hline & Mustelidae & & & & & \\
\hline \multirow[t]{2}{*}{4} & Oriental small-clawed otter & Amblonyx cinerea $^{\mathrm{TP}, \mathrm{Lr} / \mathrm{Nt}}$ & $\mathrm{Fp}$ & $\mathrm{Fp}$ & 0 & 0 \\
\hline & Suidae & & & & & \\
\hline \multirow[t]{2}{*}{5} & Wild pig & Sus scrofa, ${ }^{\mathrm{Nt}}$ & $\mathrm{Ob}$ & $\mathrm{Ob}$ & $\mathrm{Ob}$ & $\mathrm{Ob}$ \\
\hline & Cercopithecidae & & & & & \\
\hline 6 & Long-tailed Macaque & Macaca fascicularis ${ }^{\mathrm{P} \mathrm{Lr} / \mathrm{Nt}}$ & $\mathrm{Ob}$ & $\mathrm{Ob}$ & $\mathrm{Ob}$ & $\mathrm{Ob}$ \\
\hline \multirow[t]{2}{*}{7} & Dusky Leaf Monkey & Trachypithecus obscurus ${ }^{\mathrm{TP}, \mathrm{Lr} / \mathrm{Nt}}$ & $\mathrm{Ob}$ & $\mathrm{Ob}$ & 0 & 0 \\
\hline & Pteropodidae & & & & & \\
\hline \multirow[t]{3}{*}{8} & Long-tongued Nectar Bat & Macroglossus minimus ${ }^{\mathrm{Lr} / \mathrm{c}}$ & 102 & 55 & 5 & 9 \\
\hline & Total species & & 6 & 5 & 4 & 4 \\
\hline & Total family & & 5 & 4 & 4 & 4 \\
\hline
\end{tabular}

Note: $\mathrm{TP}=$ Totally protected, $\mathrm{P}=$ Protected (conservation status based on Wildlife Act 1972), P1 and P2 = transects within mangrove forest on Pulau Mat Zain, P3 and P4 = transects within mangrove forest patch west of proposed area, LR/lc = Lower Risk; Least Concern, Nt = Not threatened (conservation status based on IUCN 2000).

\section{Birds}

Although the study sites within the two mangrove forests may be considered small, and is already partly cleared due to human activities (partially due to logging and erosion), the area (reclaimed area and mangrove forests) still supported a relatively high number of bird species. From the recent survey, 57 bird species from 26 families were recorded from the study sites. Out of 57 species, only three species and 2 families were caught in mist-nets and all of these three species were also observed (Table 7 and Table 8). Once grouped according to the habitats, mangrove and reclaimed land (including from fringing vegetation, swamp and adjacent plantations), the bird community differed in their diversity and composition. Diversity and composition of birds reflect the overall characteristics and function of each of these habitats. The species richness and family of birds recorded from these two habitats were almost the same with 37 and 40 species and 17 and 19 families, respectively. Although the total number of species and family were almost the same, species compositions differed. Among the 26 families, only several families were represented by the same species such as tern, swallow, crow, heron, egret, and bittern. Families that were only or partly present in mangrove 
habitat but not the other were flycatcher, prinia, fantail, sunbird, and flower packer, while wagtail, shrike, myna, munia, and sandpiper were only present in the reclaimed habitat (open and shore habitat).

Generally, about half (33 species) of these species are totally protected (TP) under the Wildlife Act 1972. From the remaining species, 8 are game birds and others are either protected (NP) or other protected birds (OPB). The most dominant bird species found within the study site were species associated with the sea and shore such as tern, plover, bee-eater, sandpiper, and gull (Table 7 and 8). As indicated above birds from these families can easily observe in open areas (OC), which includes beaches and shore. More than half of 57 bird species recorded at the study site was resident (38 species) species. Most of them were also common, except six species which are classified by Strange and Jeyarajasingam [25] as 'Uncommon' (U). They are jungle myna, blue-tailed bee eater, red wattle lapwing, black bittern, black kite, and yellow-breasted flower packer. Among resident species, 8 species are considered important by Strange and Jeyarajasingam [25], because they use or rely heavily on mangrove (MG) habitat.

In comparison with other mangrove areas, the study areas lack intertidal mudflats. Beaches along the shorelines within the study area are sandy and already showed signs of erosion due to the existing port activities. Intertidal mudflats that are associated with major mangrove forests are very important wetland habitats because they support very rich benthic fauna. This is especially true if the mangrove forest is in an active accretion phase. These areas, in turn, also serve as feeding grounds for migratory shorebirds and resident water birds. Other than shore and water birds that rely on mudflats, many other 'forest' bird species depend on mangrove habitat. In Sepang-Lumut mangrove forest, Saberi Othman et al. [26] stated that more than 12 species of forest birds use this habitat either exclusively or partially. Among these species are Serpent eagle (Spilornis cheela), Green leafbird (Chloropsis cynopogon) and Darknecked tailorbird (Orthotomus atrogularis). From the species list generated from this survey, there is one species considered important in conservation and need a great attention since this species is classified internationally as Endangered (Vulnerable) by IUCN and listed in Appendix I CITES list. The Lesser adjutant (Leptoptilos javanicus), was observed three times and possibly of different individuals feeding along the shoreline at Pulau Che Mat Zain (Table 7). Apart from this species, there were other two species found within the proposed listed in Appendix II CITES; Mangrove Blue Flycatcher (Cyornis rufigastra) and Mangrove Whistler (Pachycephala cinerea). Both species were observed within the forest area of Pulau Che Mat Zain.

\section{Herpetofauna}

Only three species of reptiles from three families were observed from the mangrove study sites, Mangrove skink (Emoia atrocostata), Monitor Lizard (Varanus salvator) and Mangrove snake (Boiga dendrophila). Other studies conducted in mangrove areas also recorded low numbers, such as in Kuala Kedah, Kedah [23], and Kilim Forest Reserve on Langkwi Island (Personal observation). Christensen et al. [24] recorded one species of crocodile, four species of lizards and 6 species of snakes at Johor.

\section{CONCLUSIONS}

Available information indicated a decline in the quality of habitat at West Port due to land clearing, reclamation, selective logging, aquaculture, agriculture and other development activities. Large shore and migratory bird species were not seen, probably due to absence of required habitats such as mudflats. No large mammals were recorded indicating total extinction, but medium-size mammals, such as the pigs and civets, indicate that hardy species could still survive in a stressed environment. Total clearing of the mangrove habitat would eventually destroy the habitat for terrestrial fauna that totally depend on mangrove. Wildlife is particularly vulnerable to forest disturbance and clearing because they depend upon forest for the existence [20]. Many species require extensive areas of forest because required home range is large. Preserving and rehabilitating of the mangrove forests, especially on adjacent surrounding islands is proposed not only to compensate for the loss of the fragmented mangrove forests on development but also to maintain the natural mangrove ecosystem process to occur. 
Table 7. List of birds observed at proposed and surrounding areas

\begin{tabular}{|c|c|c|c|c|c|}
\hline \multirow{2}{*}{ No. } & \multirow{2}{*}{ Family } & \multirow{2}{*}{ Species } & \multicolumn{2}{|c|}{ Habitat } & \multirow{2}{*}{ Habitat/Status/ } \\
\hline & & & $\mathrm{R}$ & $\mathrm{M}$ & \\
\hline & Muscicapidae & & & & \\
\hline 1 & Mangrove Blue Flycatcher & Cyornis rufigastra $^{\mathrm{II}}$ & 0 & 2 & $\mathrm{MG}, \mathrm{R}, \mathrm{C}, \mathrm{TP}$ \\
\hline \multirow[t]{3}{*}{2} & Asian Brown Flycatcher & Muscicapa danurica & 0 & 1 & GP/MG/LF/LMF, M, C, \\
\hline & & & & & $\mathrm{TP}$ \\
\hline & Pachycephalidae & & & & \\
\hline \multirow[t]{2}{*}{3} & Mangrove Whistler & Pachycephala cinerea ${ }^{\mathrm{II}}$ & 0 & 2 & $\mathrm{MG}, \mathrm{R}, \mathrm{C}, \mathrm{TP}$ \\
\hline & Motacillidae & & & & \\
\hline 4 & Yellow Wagtail & Motacilla flava & 23 & 0 & $\mathrm{OC}, \mathrm{M}, \mathrm{C}, \mathrm{TP},-$ \\
\hline \multirow[t]{2}{*}{5} & Richards pipit & Anthus novaeseelandiae & 6 & 0 & OC, R, C, TP \\
\hline & Laniidae & & & & \\
\hline \multirow[t]{2}{*}{6} & Brown Shrike & Lanius cristatus & 3 & 0 & GP/OC, M, C, TP \\
\hline & Sturnidae & & & & \\
\hline 7 & Common Myna & Acridotheres tristis & 26 & 0 & GP/OC, R, A, NP \\
\hline 8 & Jungle Myna & Acridotheres cristatellus & 13 & 0 & OC, R, U, NP \\
\hline \multirow[t]{2}{*}{9} & Hill Myna & Gracula religiosa $^{\mathrm{II}}$ & 0 & 2 & MG/LF, R, C, OPB, - \\
\hline & Columbidae & & & & \\
\hline 10 & Spotted Dove & Streptopelia chinensis & 11 & 0 & GP/OC, R, C, NP, - \\
\hline 11 & Peaceful Dove & Geopelia striata & 18 & 0 & GP/OC, R, C, NP,- \\
\hline \multirow[t]{3}{*}{12} & Thick-billed Pigeon & Treron curvirostra & 0 & 3 & MG/LF/LMF, R, C, \\
\hline & & & & & $\mathrm{GB},-$ \\
\hline & Alcedinidae & & & & \\
\hline 13 & Common Kingfisher & Alcedo atthis & 2 & 10 & IS/MG, R\&M, C, TP, - \\
\hline 14 & Oriental Dwarf Kingfisher & Ceyx erithacus & 0 & 5 & LF, R\&M, C, TP, - \\
\hline 15 & Whited-throated Kingfisher & Halcyon smyrnensis & M & 41 & GP/OC, R, C, TP, - \\
\hline \multirow[t]{2}{*}{16} & Black capped Kingfisher & Halcyon pileata & 5 & 36 & OC/MG, M, C, TP, - \\
\hline & Meropidae & & & & \\
\hline \multirow[t]{2}{*}{17} & Blue-Tailed Bee Eater & Merops philippinus & 11 & 44 & OC, R, U, TP, - \\
\hline & Picidae & & & & \\
\hline \multirow[t]{2}{*}{18} & Common Goldenback & Dinopium Javanese & 0 & 3 & GP/OC/MG/LF, R, C, \\
\hline & & & & & $\mathrm{TP}$ \\
\hline \multirow[t]{2}{*}{19} & Brown-capped woodpecker & Picoides moluccensis & 0 & 1 & MG/LF, C, TP, - \\
\hline & Rallidae & & & & \\
\hline 20 & Common Moorhen & Gallinula chloropus & 8 & 0 & IS, R, C, GB, - \\
\hline 21 & White-breasted Waterhen & Amaurornis phoenicurus & 6 & 0 & IS, R\&M, A, GB, - \\
\hline
\end{tabular}




\section{Charadriidae}

22 Red-wattled Lapwing

23 Little Ringed Plover

\section{Scolopacidae}

24

25

26

27

28

29

31

33 Yellow-vented Bulbul

\section{Pycnonitidae}

\section{Corvidae}

34 House Crow

35 Large-billed Crow

\section{Sylviidae}

36 Ashy-Tailorbird

37 Yellow-bellied Prinia

\section{Rhipiduridae}

$38 \quad$ Pied Fantail

\section{Aredeidae}

39 Grey Heron

40 Purple Heron

41 Little Heron

42 Cattle Egret

43 Little Egret

44 Yellow Bittern

45 Black Bittern

\section{Ciconiidae}

Vanellus Indus

Charadrius hiaticula

Tringa glareola

Actitis hypoleucos

Tringa nebularia

Hydroprogne caspia

Sterna hirundo

Larus brunnicephalus

Hirundo rustica

Hirundo tahitica

Lalage nigra

Pycnonotus goiaver

Corvus splendens

Corvus macrorhynchos

Orthotomus sepium

Prinia flaviventris

Rhipidura javanica

Ardea cinerea

Ardea purpurea

Butorides striatus

Bubulcus ibis

Egretta garzetta

Ixobrychus sinensis

Dupetor flavicollis

\author{
50 OC, R, U, GB, - \\ 130 OC/MF, C, GB, -
}
70 IS/MF, M, C, GB, -
617 OC/IS/MF, M, C, GB, -
70 MF, M, C, GB, -
M M MF/CW, M, RA, NP, -
M M CW, M, C, TP, -
-
-

M M OC, M, A, TP, -

M M OC, R, C, TP, -

M M GP/ OC, R, C, TP, -

170 GP/OC, R, A, NP, -
2319 GP/OC, I, A, NP, -
M M GP/OC/LF/LMF, R, C, NP, -
04 MG/LF, R, C, TP, -
01 OC, R, C, TP, -

04 MG/LF, R, C, TP, -

54 MG/MF, R, C, TP, -

62 IS, R\&M, C, TP, -

410 IS/MG/MF, R\&M, A, $\mathrm{TP}$, -

$\begin{array}{ccl}8 & 5 & \text { OC, M, C, TP, - } \\ 35 & 33 & \text { IS/MG/MF, M, C, TP, - } \\ 0 & 3 & \text { IS, R\&M, C, TP, - } \\ 5 & 2 & \text { IS, M, U, TP, - }\end{array}$




$\begin{array}{llllll}46 & \text { Lesser adjutant } & \text { Leptoptilos javanicus } & & \\ & \text { Accipitridae } & & 3 & \text { MG, MF, IS, R, U, TP,- } \\ 47 & \text { Black-shouldered Kite } & \text { Elanus caerulus } & 2 & 1 & \text { OC, R, C, TP, - } \\ 48 & \text { Black Kite } & \text { Milvus migrans } & 9 & 11 & \text { OC/MG, M, U, TP, - } \\ 49 & \text { Brahminy Kite } & \text { Haliastur indus } & 14 & 47 & \text { MG, R, A, TP, - } \\ & \text { Nectariniidae } & & & \\ 50 & \text { Brown-throated Sunbird } & \text { Anthreeptes malaccensis } & 0 & 2 & \text { GP/OC/MG, R, C, P, - } \\ 51 & \text { Copper-throated Sunbird } & \text { Nectarinia calcostetha } & 0 & 2 & \text { MG, R, C, TP, - } \\ 52 & \text { Olive-backed Sunbird } & \text { Nectarinia jugularis } & 0 & 4 & \\ & \text { Dicaeidae } & & & \\ 53 & \text { Yellow-breasted Flowerpecker } & \text { Prionochilus maculates } & 0 & 3 & \text { LF/LMF, R, U, TP, - } \\ & \text { Zosteropidae } & & & \\ 54 & \text { Oriental White-eye } & \text { Zosterops palpebrosa } & 0 & 12 & \text { MG, R, C, OPD, - } \\ & \text { Estrildidae } & & & \\ 55 & \text { Scally-breasted Munia } & \text { Lonchura punctulata } & 23 & 0 & \text { GP/OC, R, C, NP, - } \\ 56 & \text { Chestnut-Munia } & 20 & 0 & \text { OC, R, C, NP, - } \\ 57 & \text { White-headed Munia } & \text { Lonchura malacca } & \text { Lonchura maja } & 0 & \text { OC, R, C, NP, - } \\ & \text { Total species } & 49 & 40 & \\ \text { Total family } & & 19 & \end{array}$

Note: Habitat: GP=Garden and parks, OC=Open country, IS=Inland freshwater swamps, LF=Lowland, LMF $=$ Lowland mountain forest, $\mathrm{UMF}=$ Upper mountain forest. Status: R=Resident, M=Migrant. Law (Wildlife Act): $\mathrm{TP}=$ Totally protected, $\mathrm{P}=$ Protected, $\mathrm{NP}=$ Not protected, $\mathrm{GB}=$ Game Bird.

Table 8. List of birds netted at proposed and surrounding areas (mangrove)

\begin{tabular}{|c|c|c|c|c|c|c|}
\hline \multirow{2}{*}{ No. } & \multirow{2}{*}{ Family / Common Names } & \multirow{2}{*}{ Spesies } & \multicolumn{4}{|c|}{ Habitat } \\
\hline & & & P1 & $\mathbf{P 2}$ & $\mathbf{P 3}$ & $\overline{\mathbf{P 4}}$ \\
\hline & Alcedinidae & & & & & \\
\hline 1. & Black capped Kingfisher & Halcyon pileata & 0 & 0 & 1 & 1 \\
\hline \multirow[t]{2}{*}{2.} & White-collared Kingfisher & Todiramphus chloris & 4 & 5 & 2 & 0 \\
\hline & Nectariniidae & & & & & \\
\hline \multirow[t]{4}{*}{3.} & Brown-throated Sunbird & Anthreeptes malaccensis & 0 & 2 & 0 & 0 \\
\hline & Total species & & 1 & 2 & 2 & 1 \\
\hline & Total family & & 1 & 2 & 1 & 1 \\
\hline & Total individuals & & 4 & 7 & 3 & 1 \\
\hline
\end{tabular}

Note: P1 and P2 = Sites at Pulau Che Mat Zain (dotted lines at south and north, respectively - see Figure 1), P3 and P4 $=$ Sites at West Port (dotted lines at south and north, respectively - see Figure 1) 


\section{REFERENCES}

1. Wetlands International-Malaysia Programme. 2000. Klang Islands Group: Issues and needs for conservation. A working paper submitted to the Selangor Forestry Department. Wetlands International-Malaysia Programme, Petaling Jaya. 19 pp.

2. Kuala Langat District Council. 1994. Kuala Langat and Sepang District Structure Plan. Town Planning Department, Kuala Langat District Council, Malaysia.

3. Kuala Langat District Council. 2000. Structure Plan of Kuala Langat, Sepang and Putrajaya. Town Planning Department, Kuala Langat District Council, Malaysia.

4. Majlis Perbandaran Klang. 2000. Plan Report 1990-2000. Klang Municipal Council.

5. Gong, W.K. 1984. Mangrove primary productivity. Proc. Workshop Mangr. Prod. Universiti Sains Malaysia, Penang, Malaysia.

6. Ong, J.E., Gong, W.K. and Dhanarajan, G. 1984. Contribution of aquatic productivity in managed mangrove ecosystem in Malaysia p. 209-215. In Soepadmo A.N. and Macintosh, D.J. (eds.). Proc. Asian Sympo. Mangr. Envron. University of Malaya, Malaysia.

7. Gong, W.K., Ong, J.E. and Clough, B.F. 1992. Photosynthesis in different aged stands of a Malaysian mangrove ecosystem. In Chou, I.M. and Wilkinson, C.R. (eds.). Proc. Marine Science and Living Coastal Resources 6: 21-23.

8. Ong, J.E., Gong, W.K. and Wong, C.H. 1985. Seven years of productivity studies in a Malaysian managed mangrove forest: then what? In. K.N. Bardsley, J.D.S. Davies and C.D. Woodroffe. (eds.) Coasts and Tidal Wetlands of the Australian Monsoon Region. Australian National University, North Australian Research Unit, Darwin, Monograph No. 1, pp. 213-223.

9. Putz, F.E. and Chan, H.T. 1986. Tree growth, dynamics, and productivity in a mature mangrove forest in Malaysia. For. Ecol. Mgmt. 17: 211-230.

10. Clough, B.F. and Scott, K. 1989. Allometric relationship for estimating above ground biomass in 6 mangrove species. For. Ecol. \& Mgmt. 27: 117-127.

11. Lugo, A. E. \& Snedaker, S. C. 1974. The ecology of mangroves. Annu. Rev. Ecol. Syst. 5:39-64.

12. Curtis, J.T. and Macintosh, R.P. 1951. An upland forest continuum in the prairie-forest border region of Wisconsin. Ecology 32: 476-496.

13. Mori, S.A., Boom, B.M., Carvalino, A.M. \& Dos Santos, T.S. 1983. Ecological importance of
Myrtaceae in an eastern Brazilian wet forest. Biotropica 15: 68-70.

14. Adam, J. H., Walid, A. S., Omar, R. \& Jalaludin, A. K. 2003. Prosiding Simposium Biologi Gunaan ke-7, Mines Beach Resort \& Spa, Seri Kembangan, Selangor 3-4 Jun 2003. (Ed.). Adam, J. H., Ali, Z. M., Ibrahim, N., Md-Zain, B. M. \& Omar, R. pp. 430-433.

15. Tanouchi, H., Nakamura, S., Ochiai, Y. \& Hassan, H. 2000. Stand structure and aboveground biomass of a mangrove forest in Matang, Peninsular Malaysia. JIRCAS International Workshop Brackish Water Mangrove Ecosystems: Productivity and Sustainable Utilization 29 Feb-1 Mar 2000, Tsukuba, Japan. Pp. 35-38.

16. Fromard, F., Puig, H., Peltier, A., Betoulle, J.L., Mougin, E. and Marty, G. (1997). Structure, dynamics, and biomass of the mangroves in French Guiana. Boletim do Museu Paraense Emilio Goeldi Serie Ciencias da Terra 8: 5-29.

17. Hong, P.N. and San, H.T. 1993. Mangroves of Vietnam. The IUCN Wetlands Programmes, IUCN, Bangkok, Thai, 173 pp.

18. Mazda, Y., Magi, M., Kogo, M. and Hong, P.N. 1997. Mangroves as a coastal protection from waves in the Tong King delta, Vietnam. Mang. Salt Marsh. 1 (2): 127-135.

19. Jiao, J. J., Nandy, S., \& Li, H. 2001. Analytical studies on the impact of land reclamation on ground water flow. Ground Water 39 (6): 912920.

20. Medway, L. 1983. The wild mammals of Malaya and Singapore. Oxford University Press.

21. Payne, J., C. M. Francis, and K. Philipps. 1985. A field guide to the Mammals of Borneo. Kota Kinabalu: The Sabah Society.

22. Saberi Othman, Jambari Hj. Ali, Ahmad Ismail, Zakaria Sulaiman \& Razali Salam. 1993. Biological aspects of Sepang-Lukut mangrove forests. Proceedings of Tropical Resources Symposium, 6-8 December 1993 Kuching Sarawak.

23. Shukor M. N. and Mohd Sham Othman, 2000. Fauna of Mangrove area in Kuala Kedah. Unpublished report.

24. Christensen, B. \& Olsen, P. 1999. Biodiversity audit and conservation plan for the mangroves of Johor. Project Document No. 6 from the FD/DANCED Project: Preparation of an integrated management plan for sustainable use of the Johor mangroves 1997/1999. Johor Baru, Malaysia.

25. Strange, M., and Jeyarajaingam, A. 1993. Birds: A photographic guide to the birds of Peninsular Malaysia and Singapore. A Sun Tree Notebook. 